\title{
Environment, agro-system and quality of food production in Italy
}

\author{
Nicola Dal Ferro, Maurizio Borin \\ Department of Agronomy, Food, Natural resources, Animals and Environment, University of Padua, \\ Legnaro (PD), Italy
}

\begin{abstract}
In the context of increasing attention towards sustainable and high quality food products, Italy plays a key role in Europe due to its embedded territorial vocation for locally produced food and alternative agriculture systems helping biodiversity and landscape preservation. Here, we report an overview of Italian agriculture by analysing organic farming (OF) and geographical indication (GI) systems and their contribution to the national agriculture. Land use data highlight that OF and GI contribute around $10 \%$ to the utilised agriculture area (UAA), with relevant distinctions in terms of regional distribution. While GIs are mostly in the north-central regions $(8.5 \%)$, OF products are most frequent in the south and on the islands ( $5.0 \%$ of UAA). This trend was observed on the one hand in Trentino-South Tirol, Veneto and Friuli-Venezia Giulia (\%UAA GI/\%UAA OF>5.9), and on the other in Calabria, Basilicata and Sicily (\%UAA GI/\%UAA OF $<0.1)$. Similarly, both systems are widespread in less-favoured areas in terms of agricultural intensification, providing support to preserve agro-systems and reduce land abandonment.
\end{abstract}

\section{Introduction}

High quality and authentic agri-food products, mostly recog-

Correspondence: Nicola Dal Ferro, Department of Agronomy, Food, Natural resources, Animals and Environment, University of Padua, viale dell'Università 16, 35020 Legnaro (PD), Italy.

Tel.: +39.049.8272818 - Fax: +39.049.8272839.

E-mail: nicola.dalferro@unipd.it

Key words: Land use; Agricultural systems; Geographical indications; Organic farming.

Acknowledgments: research supported by CIRVE with financial support of Veneto Region (Regional Law $5^{\text {th }}$ April 2013), and University of Padua Special Projects.

Received for publication: 3 May 2016.

Revision received: 2 June 2016.

Accepted for publication: 6 February 2017.

(C) Copyright N. Dal Ferro and M. Borin, 2017

Licensee PAGEPress, Italy

Italian Journal of Agronomy 2017; 12:793

doi:10.4081/ija.2017.793

This article is distributed under the terms of the Creative Commons Attribution Noncommercial License (by-nc 4.0) which permits any noncommercial use, distribution, and reproduction in any medium, provided the original author(s) and source are credited. nised as coming from organic farming or labelled with geographical indications (Aprile et al., 2012), are increasing in Europe as consumers consider quality, and its association with agro-ecological characteristics (Deselnicu et al., 2013), the most important purchasing factor (e.g., Malorgio et al., 2008; Hinojosa-Rodríguez et al., 2014; Special Eurobarometer 410, 2014). In this context, the Universal Exposition that was held in Milan during 2015, entitled Feeding the Planet, Energy for Life, emphasised the need for sustainable agricultural products and the importance of quality food.

The adoption of quality brands in Europe in the 1990s was intended to encourage the diversification of agricultural production and protect product names and processes that are linked to a geographical area through the promotion of Protected Designation of Origin (PDO) and Protected Geographical Indication (PGI) labels (i.e., geographical indications, GI), under Council Regulation (EEC) No 2081/92 (European Commission, 1992). Moreover, by adopting Regulation (EEC) No 2092/91 (European Commission, 1991), the European Council of Agricultural Ministers introduced organic farming (OF) and the labelling of organic farm produce and foods with the aim of promoting sustainable alternatives to conventional agriculture. In spite of being adopted with different purposes, over the years both schemes confirmed their vocation as producers of quality food. Their assembly into a single, although varied, product category (called sustainable produced food) was also proposed by Vermeir and Verbeke (2006) since they both reflect two different components of sustainability: i) a social component in support of the local agri-food sector and rural citizens - in the case of geographical indication products; ii) an environmental component related to sustainable use and management of natural resources - in the case of organic farming products.

Since 2004, organic farmland in the EU increased by approximately $76 \%(+3 \%$ in 2013 on a yearly basis), involving an increase of the organic market that reached $+55 \%(+6 \%$ in 2013 on a yearly basis) (Willer and Schaack, 2015). Similarly, the sales value of geographical indication products registered in the EU 27 increased by $12 \%$ between 2005 and 2010 (Chever et al., 2012), while their area of production is strictly related to their specific geographical origin and regulations.

In addition to economic return, quality produced foods have been recognised as contributors to maintaining biodiversity and enhancing environmental benefits. In particular, organic farming was proposed in the EU as a certification process to minimise human impact on the environment, by ensuring that agriculture operates in the most natural way. Among others Tuomisto et al. (2012), in a meta-analysis study conducted on European data, showed that organic farming systems had generally lower environmental impacts than conventional farming, although they also stated that there was not an optimal system for all the measures that were adopted to improve environmental practices as also found by others (Dal Ferro et al., 2016). Although environmental protection is not explicitly addressed either in EU legislation or in national requirements for the protection of geographical indica- 
tions, several studies reported their general favourable effect. An overall capacity was observed to maintain multifunctional agricultural systems (Belletti et al., 2003), landscapes and biodiversity thanks to the protection of small-scale production and conservation of local ecosystems (Bérard and Marchenay, 2006). However, some weaknesses were also highlighted, such as the risk of favouring genetic erosion in plant varieties and animal breeds (Thévenod-Mottet, 2010). In this context, some studies reported that EU member states with a strong tradition and well-developed systems of geographical indication protection (in particular France and Italy) are also characterised by the highest level of environmental care (Belletti et al., 2015).

Italian agriculture is recognised worldwide as providing agrifood products and brands of prime quality. Within EU member states, Italy is one of the most important in terms of utilised agricultural area (UAA) and sustainably produced foods. An integrated analysis of the Italian agro-systems involved in quality food production is therefore a key aspect for assessing the agricultural sector's state of the art and evaluating potential future developments. Since both systems can indicate increased environmental quality and provide multiple ecosystem services, although partly addressed towards different environmental protection issues (e.g., low human impact in OF; landscape protection in GI), the understanding of their characteristics and relationship in the national context is crucial to address targeted agri-environmental policies. In this context, this study provides an overview of OF and GI systems and their relationship across Italy and their influence on the agricultural sector. In particular, the paper aims to describe: i) size and distribution of OF and GI farms in comparison to the total farms in Italy; ii) the distribution of OF and GI systems in the different regions, in relation to the respective farming systems; iii) the UAA cultivated with OF and GI in the different elevation zones and macroareas in Italy; iv) the repartition of the main crop categories within both OF and GI systems; v) the distribution of GI agri-food products and wines in the Italian macro regions and the national contribution with respect to EU and World products.

\section{Materials and methods}

A general overview of different agricultural land uses at a national level is provided by the National Institute of Statistics (ISTAT), which is the main supplier of official statistics in Italy. In this paper, data from the last national agricultural census (hereafter labelled as ISTAT 10), conducted in 2010 (ISTAT, 2010) at the municipal level, were used to study the Italian agricultural sector at the national (NUTS-1), regional (NUTS-2) and sub-regional level. In particular, a comparison was done between conventional farming systems and those labelled according to OF and GI in terms of localisation, average farm size (ha), area investment (ha) per product category (e.g. cereals, vegetables, etc.). Moreover, municipal data were grouped into sub-regional macroareas following the ISTAT classification as follows (Figure 1A): North, comprising Aosta Valley, Piedmont, Liguria, Lombardy, TrentinoSouth Tirol, Veneto, Friuli-Venezia Giulia and Emilia-Romagna regions; Centre, comprising Tuscany, Marche, Umbria and Lazio regions; South, comprising Abruzzo, Molise, Campania, Apulia, Basilicata and Calabria regions; Islands, comprising Sardinia and Sicily. Following the ISTAT classification, a comparison also was done on data belonging to different altitudinal areas (mountain, hills and plain) (Figure 1B).

Additional information was obtained from the CORINE (Co-
ORdination on INformation of the Environment) Land Cover geographic database at national (NUTS-1) and regional (NUTS-2) level. CORINE has a minimum cartographic unit of 25 ha and a geometric accuracy of $100 \mathrm{~m}$. It maps homogeneous landscape patterns, i.e. more than $75 \%$ of the pattern has the characteristics of a given class from the nomenclature. Information from the CORINE Land Cover database used here refers to agricultural areas (Level 2) as divided in Arable lands, Permanent crops, Pastures and Heterogeneous agricultural areas. The time reference for CORINE Land Cover classification is 2012 (hereafter labelled as CLC 12; CLC, 2012).

Organic farming in the EU has been regulated since the beginning of the 1990s. The uniform EU regulation for the production, control, labelling and import of organic products has been revised several times since its introduction [Regulation (EEC) No 2092/91; European Comission, 1991] and has been replaced with the current Organic Regulation (EC) 834/2007 (European Comission, 2007) and further minor changes. A special mention must be made about organic wine production. Until 2012 an organic wine was intended as produced from organic grapes only. In 2012, the EU approved a regulation governing the production of organic wine and the option to put the EU organic logo on the label, as with other organic foods. The novelty is that organic wine must be produced from organic grapes and vinified according to EU specific regulations as per other agri-food products [Regulation (EU) No 203/2012; European Comission, 2012a].

Two EU schemes, known as Protected Designation of Origin (PDO) and Protected Geographical Indication (PGI), are here integrated in the more general Geographical Indication (GI) wording, including place-based agri-food and wine products. In 1992, a regulation (EC 2081/92; European Comission, 1992) was issued with the aim of protecting PDO and PGI and giving a certain guarantee to consumers by defining the conditions, procedures, and extent of protection. The legislative framework adopted by the EU and that is currently in force [Regulation (EU) No 1151/2012; European Comission, 2012b] provides that producers apply for the GI protection. They are required to submit an application accompanied by product specifications that contain rules for the production process and the area within which the product is produced, thus linking the agri-food production with specific rural culture and local geographical aspects in the definition of terroir (Bérard and Marchenay, 2006). Once again, the wine sector followed a different piece of legislation and its integration within the same legislative scheme as per other agri-food products occurred with Regulation (CE) No 479/2008 (European Comission, 2008).

International statistics on the number of GI products in the different countries were obtained from the official EU web pages regarding agri-food (http://ec.europa.eu/agriculture/ quality/ door/list. html; last update 26/01/2017) and wine (http://ec.europa.eu/agriculture/markets/wine/e-bacchus; last update 26/01/2017), while the number of regional GIs across Italy (agri-food and wine products) was obtained from the Italian Ministry of Agriculture web page (https://www. politicheagricole.it/; last update 26/01/2017) .

\section{Results and discussion}

\section{The Italian environment}

According to Finke et al. (1998) Italy is characterised by a wide variation of climatic conditions, from temperate to 
Mediterranean, suggesting the interaction of a continental climate (northern and central-northern areas) with that of the Mediterranean basin (centre, south and islands). Moreover, the diversification of almost all the national regions in several elevation zones (plain, hill and mountain), from the sea level (surrounding almost all the country) to the high mountains in the north (the highest peak in Europe is Monte Bianco in the Aosta Valley region,
$4810 \mathrm{~m}$ asl) is a second major aspect characterising the national territory. Descriptive statistics for simplified climatic regions are reported in Table 1 (L'Abate and Costantini, 2004). By overlaying climatic-orographic aspects with the pedological characteristics of Italy (Costantini et al., 2004; Costantini et al., 2013), a national fragmentation can be noticed that gives 43 unique pedo-climatic areas (Figure 1D). In this context, the northern regions have the


Figure 1. Regions of Italy (A) as labelled with different colours to define North, Centre, South and Islands macroareas; elevation zones (B) and climatic areas (C); number of pedo-climatic units per region as a result of climatic and pedological overlay (D). 
lowest territorial diversification (7.0 pedo-climatic units, on average), while central Italy has the highest (14.3, on average). The south and islands account for 11.0 and 12.0 pedo-climatic units on average. This diversity is not related to the territorial extensions of the regions since Tuscany, Umbria, Lazio and Marche (central regions) occupy only $19.7 \%$ of the national territory, whereas the north occupies the largest area (38.7\%).

\section{Italian agricultural systems}

Italy's utilised agricultural area (UAA) currently occupies $42.6 \%$ of the territory, ranging from a minimum of $37.0 \%$ in the centre (Lazio, Marche, Tuscany and Umbria regions) to a maximum of $50.9 \%$ on the islands (Sardinia and Sicily regions). A comparison with historical data underlines a negative trend of UAA in Italy, which decreased from 17.5 million ha ( $c a .58 \%$ of national area) in 1970 to the current 12.9 million ha, with an average annual decrease of $-0.65 \%$ (Figure 2). By contrast, since 1975 the UAA in the EU-9 has remained almost stable at over 80 million ha according to the farm structure survey database (EUROSTAT, 2010). However, there has been an increase of UAA on the Italian islands since 2000 and a slowdown of the negative trend, particularly in central Italy.

A general overview of Italian agriculture land use is provided by land cover maps from the Corine Land Cover 2012 inventory (Table 2). More than half of the agricultural land is occupied by arable lands $(53.5 \%)$, which include both rainfed and irrigated fields, while permanent crops (e.g., vineyards, olive groves, etc.) cover $14 \%$, with a strong differentiation between the north-centre
( $8.5 \%$, on average) and south-islands (18.6\%, on average) macroareas. Pastures and meadows are instead quite common in the northern regions reaching average values of $12.1 \%$, thus $9.4 \%$ more than the average national value (Table 2). This high figure in the north is mainly due to Aosta Valley and Trentino-South Tirol regions where pastures and meadows cover $c a$. $40 \%$ of UAA (Figure 3).

Land use data aggregation generally highlights a good correspondence with the CLC 12 ones (Figure 3): in particular, a good correlation was observed for arable lands $(\mathrm{y}=1.02 \mathrm{x}+2.3$; $\left.\mathrm{R}^{2}=0.90\right)$, estimated as $54.5 \%$ of the national territory $(+1.0 \%$ with respect to CLC 12), and permanent crops $\left(\mathrm{y}=\mathrm{x}+5.1 ; \mathrm{R}^{2}=0.77\right)$, estimated as $18.5 \%$ of the national territory $(+4.5 \%$ with respect to CLC 12). A mismatch was observed comparing the remaining UAA since land use data report that $26.7 \%$ is managed as pastures and meadows and only $0.25 \%$ for other agricultural uses (Table 2). This discrepancy was already observed by Pelorosso et al. (2009), who stated that marginal areas with low human impact (e.g., meadowlands) are likely overestimated by census data because they may no longer be farmed and thus subjected to spontaneous recolonisation. As a result land use data may suffer from a low level of reliability, particularly for those areas that are subjected to abandonment. In contrast, cartographic data (here, CLC 12) are more easily validated in the field, although the minimum mapping unit of CLC 12 (25 ha) may result in an overall increase of poorly defined categories (i.e., heterogeneous areas/other uses), which often correspond to a mixture of non-uniform areas (agricultural lands combined with natural vegetation, complex cultivation pat-

Table 1. Descriptive statistics of climatic regions of Italy.

\begin{tabular}{|c|c|c|c|c|c|c|c|}
\hline ID & Climatic areas & $\begin{array}{c}\text { Annual } \\
\text { temperature } \\
\left({ }^{\circ} \mathrm{C}\right)\end{array}$ & $\begin{array}{l}\text { Annual } \\
\text { rainfall } \\
\text { (mm) }\end{array}$ & $\begin{array}{l}\text { Elevation } \\
\text { range } \\
\text { (m) }\end{array}$ & $\begin{array}{l}\text { Wettest } \\
\text { months }\end{array}$ & $\begin{array}{l}\text { Driest } \\
\text { months }\end{array}$ & $\begin{array}{c}\text { Extension } \\
\text { (\%) }\end{array}$ \\
\hline A & Alpine region & $2.8-10.7$ & $838-1510$ & $0-4000$ & Oct, May-Jun & July & 17.7 \\
\hline B & Po Plain sub-continental region & $10.9-13.0$ & $710-1030$ & $0-600$ & Oct & July & 17.5 \\
\hline $\mathrm{C}$ & Northern Apennines sub-continental regions & $8.9-13.5$ & $1000-1540$ & $100-2000$ & Oct, Nov & July & 13.4 \\
\hline D & Southern Apennines sub-continental regions & $10.4-15.4$ & $725-1160$ & $0-2500$ & Jan & Aug & 8.4 \\
\hline E & Coastal Mediterranean regions & $11.7-16.4$ & $735-1180$ & $0-1300$ & Oct, Jan & July-Sept & 17.7 \\
\hline $\mathrm{F}$ & Semi-arid Mediterranean regions & 13.9-18.5 & $560-1130$ & $0-1700$ & Oct, Jan & July-Sept & 17.4 \\
\hline$\underline{G}$ & Arid Mediterranean regions & $14.8-18.9$ & $420-710$ & $0-650$ & Nov & May-Sept & 7.8 \\
\hline
\end{tabular}

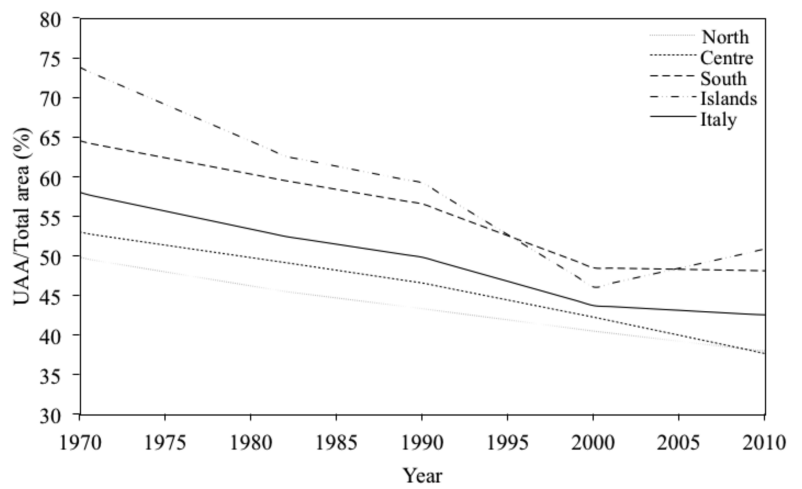

Figure 2. Italian trend of utilised agricultural area (data source: ISTAT, 2010)

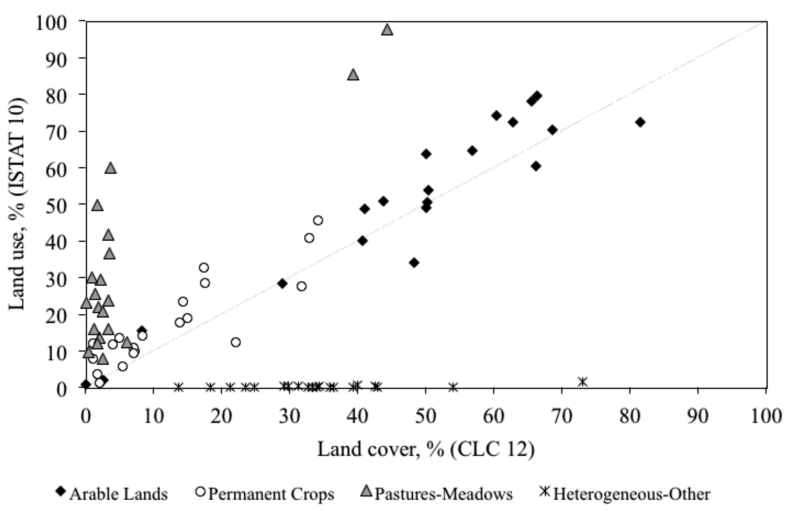

Figure 3. Relationship between regional land cover (CLC 12) and land use (ISTAT 10) data. 
terns, etc.). Conversely, field surveys likely classify them according to more defined categories (e.g. pasture, arable lands, etc.). This is particularly emphasised in the case of Italy, where estimates of land fragmentation (the average farm size is only 7.9 ha, generally implying small field size) are similar to those reported in similar studies conducted in Greece (Benaki et al., 2012). In fact, the authors observed a discrepancy between Corine Land Cover data and those reported in the Farm Structure Survey for Greece that was partly explained by the small farm size. Lastly, heterogeneous/other areas as defined by the Italian national census represent only $0.25 \%$ of UAA, although their contribution to increasing landscape diversity is relevant since they are mainly woodlands, buffer zones and unproductive/naturalised areas.

\section{The high quality agricultural sector in Italy}

Italy, with 1.3 million ha, is the second European country for total organic agriculture area, following Spain (1.6 million ha) and followed by France and Germany (1.1 million ha each). Worldwide, only Australia (17.2 million ha), Argentina (3.2 million ha), USA (2.2 million ha) and China (2.1 million ha) have larger areas of OF systems than Italy (Willer and Lernoud, 2015). OF contributes 781,489 ha to the national UAA, corresponding to $6.1 \%$ of total UAA and ranging between a minimum of $3.7 \%$ in the plain areas to a maximum of $8.3 \%$ in the hilly ones (Table 3 ).
In absolute terms, the north-centre regions have less OF systems than the southern ones and the islands as they occupy only $29 \%(227,139 \mathrm{ha})$ of the total organic farming UAA, while their contribution to the national agricultural land is $52.5 \%$. This is also confirmed by percentage data (Figure 4A), which show a general increase towards larger OF areas from north, to south and the islands. In particular, the southern regions of Calabria and Basilicata have the most land managed following OF systems (up to $18 \%$ ), while Aosta Valley (north-west), Trentino-South Tirol, Friuli-Venezia Giulia and Veneto (north-east) reach a maximum of only $1.5 \%$. This geographical trend is instead not observed for the average OF holding size at regional level (Figure 4B), which ranges between a minimum of 5.4 ha (Trentino-South Tirol) and a maximum of 43.8 ha (Sardinia) resulting, on a national scale, as double (15.9 ha) that of the average farm size (Table 3). Nevertheless, it was observed that organic farms are also distributed (i.e., as generally the farms in Italy) in terms of altitudinal areas, with the largest ones being more frequently found in the mountains than in the hilly and plain areas (Table 3).

Within the same macroarea (Figure 5), it can be noted that $\mathrm{OF}$ is generally more developed in the mountain and hilly areas, covering 5.3 and $8.3 \%$ of total UAA, than in the plain areas where, on the contrary, only $3.7 \%$ of farmland is managed following OF certifications. A general overview of land use repartition within $\mathrm{OF}$

Table 2. Utilised agricultural area repartition as a result of both Corine Land Cover 2012 (CLC, 2012) and the Italian Agricultural Census 2010 (ISTAT, 2010).

\begin{tabular}{|c|c|c|c|c|c|c|c|}
\hline \multirow{2}{*}{$\begin{array}{l}\text { UAA (\%) } \\
\text { Arable lands }\end{array}$} & & & North & Centre & South & Islands & Italy \\
\hline & $\begin{array}{l}\text { CLC } 12 \\
\text { ISTAT } 10\end{array}$ & $\begin{array}{l}\text { Cereals } \\
\text { Industrial crops } \\
\text { Fodder } \\
\text { Vegetables } \\
\text { Fallow } \\
\text { Others }\end{array}$ & $\begin{array}{c}42.15 \\
45.84 \\
21.2 \\
3.8 \\
10.7 \\
2.6 \\
3.0 \\
4.5\end{array}$ & $\begin{array}{c}55.80 \\
64.51 \\
4.9 \\
1.0 \\
4.1 \\
0.3 \\
1.3 \\
0.6\end{array}$ & $\begin{array}{c}47.17 \\
50.07 \\
21.9 \\
1.0 \\
9.6 \\
2.6 \\
4.7 \\
1.8\end{array}$ & $\begin{array}{c}49.15 \\
41.59 \\
0.1 \\
0.0 \\
0.2 \\
0.0 \\
0.0 \\
0.0\end{array}$ & $\begin{array}{c}53.49 \\
54.52 \\
28.1 \\
3.1 \\
14.9 \\
2.3 \\
4.3 \\
1.7\end{array}$ \\
\hline Permanent crops & $\begin{array}{l}\text { CLC } 12 \\
\text { ISTAT } 10\end{array}$ & $\begin{array}{l}\text { Vineyards } \\
\text { Olive groves } \\
\text { Citrus groves } \\
\text { Orchards } \\
\text { Others }\end{array}$ & $\begin{array}{c}7.40 \\
12.16 \\
6.1 \\
1.5 \\
0.0 \\
3.9 \\
0.6\end{array}$ & $\begin{array}{c}9.61 \\
16.17 \\
4.8 \\
8.4 \\
0.0 \\
2.3 \\
0.6\end{array}$ & $\begin{array}{c}18.66 \\
25.68 \\
4.9 \\
15.7 \\
1.3 \\
3.6 \\
0.2\end{array}$ & $\begin{array}{c}18.49 \\
16.70 \\
4.9 \\
7.7 \\
2.1 \\
1.8 \\
0.2\end{array}$ & $\begin{array}{c}14.04 \\
18.52 \\
5.2 \\
8.7 \\
1.0 \\
3.3 \\
0.3\end{array}$ \\
\hline Pastures and meadows & $\begin{array}{l}\text { CLC } 12 \\
\text { ISTAT } 10\end{array}$ & & $\begin{array}{l}12.13 \\
41.64\end{array}$ & $\begin{array}{c}2.69 \\
18.97\end{array}$ & $\begin{array}{c}2.02 \\
23.84\end{array}$ & $\begin{array}{c}1.81 \\
41.58\end{array}$ & $\begin{array}{c}2.72 \\
26.71\end{array}$ \\
\hline Other uses & $\begin{array}{l}\text { CLC } 12 \\
\text { ISTAT } 10\end{array}$ & & $\begin{array}{c}38.33 \\
0.36\end{array}$ & $\begin{array}{c}31.89 \\
0.34\end{array}$ & $\begin{array}{c}32.16 \\
0.42\end{array}$ & $\begin{array}{c}30.55 \\
0.13\end{array}$ & $\begin{array}{c}29.74 \\
0.25\end{array}$ \\
\hline
\end{tabular}

UAA, utilised agricultural area; CLC 12, Corine Land Cover (2012); ISTAT 10, ISTAT (2010).

Table 3. Overall average size of farms in Italy and those managed with organic farming and geographical indications systems (data source: ISTAT, 2010).

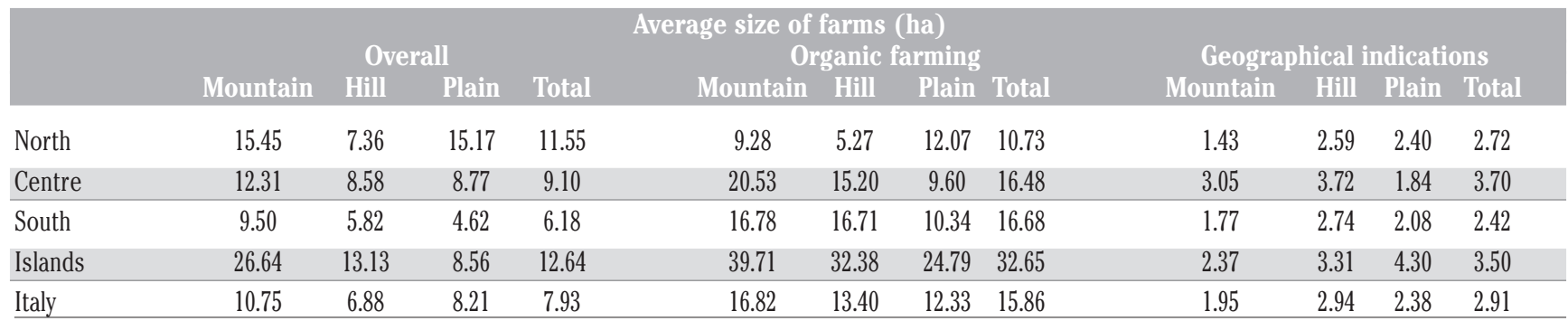


systems is proposed in Table 4. In this context, large areas that adopt organic pasture both in the north and on the islands, as well as those managed with organic cereals (mainly wheat) and olive groves in the central and southern regions (Table 4), are explained by the different incidence of altitudinal areas. In fact, agricultural intensification is more difficult in hilly and mountain areas than in the lowlands due to biophysical and management limitations
(Parrott et al., 2002), thus encouraging the adoption of alternative systems (e.g., organic farming) that can improve agro-system multi-functionality with quality products, landscape and environmental preservation (e.g., Ronchi and Nardone, 2003). This is particularly true for the northern regions, where a positive correlation $\left(\mathrm{R}^{2}=0.7, \mathrm{P}<0.001\right)$ was found between the land percentage of total $\mathrm{OF}$ and hilly areas, emphasising a distinction between intensive
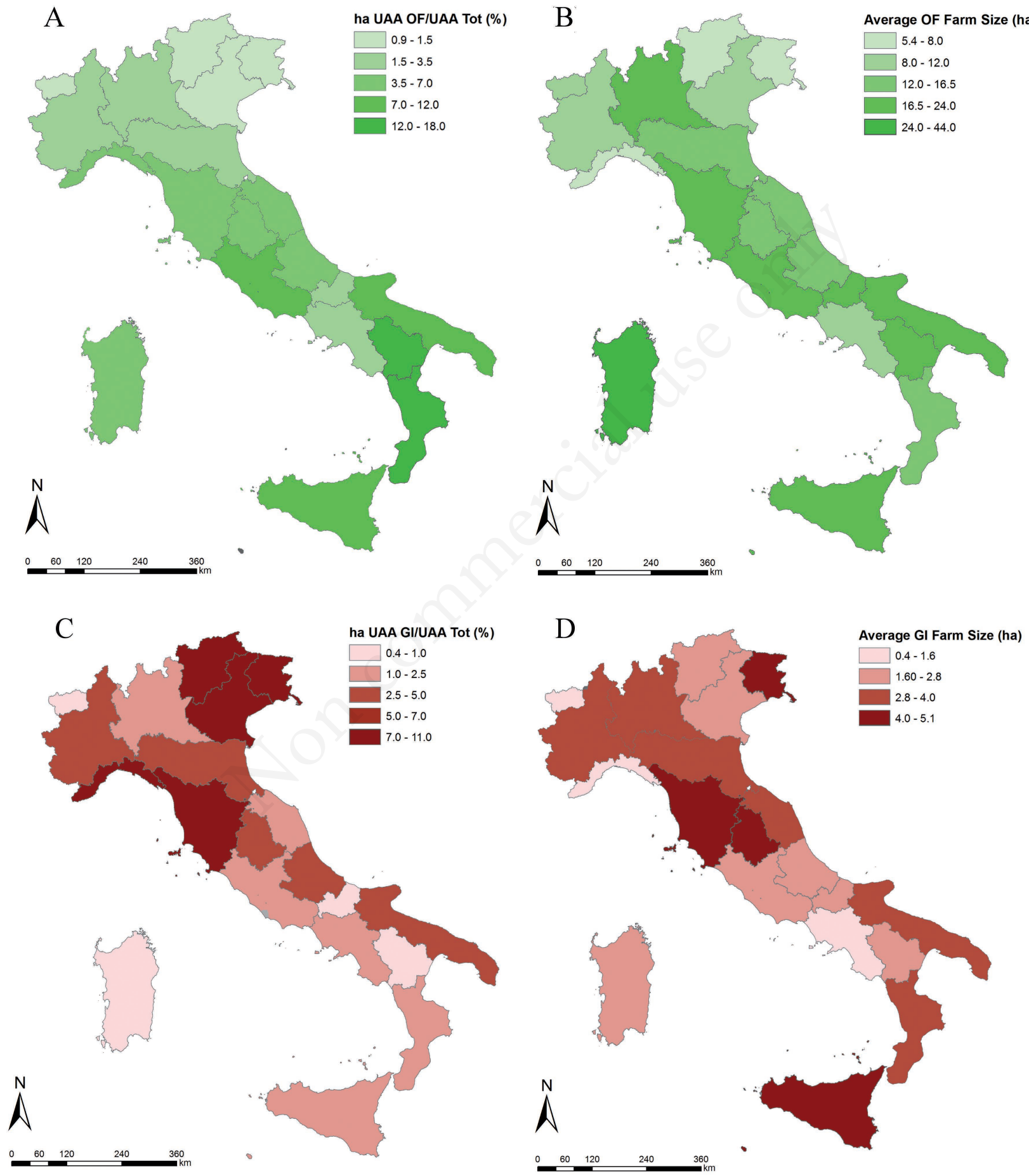

Figure 4. Utilised agricultural area and average farm size for organic farming (A and $B$ ) and geographical (C and D) indications in the Italian regions (data source: ISTAT, 2010). 
agriculture (in the lowlands) and a wider diversification in less favoured areas. Vineyards play only a secondary role in the overall organic land use. In this case, two different factors likely contribute to limiting the diffusion of organic wine production: primarily, it must be noted that a specific regulation (EU No 203/2012) for organic wine production was introduced only in 2012 , thus not yet been approved at the time of the national agricultural census and therefore limiting the potential wine market; secondly, some authors argue that the issue of organic vs conventional systems would be of limited importance for wine since the country of origin is consistently of greater importance than the production method when it comes to wine purchasing decisions (e.g., Mann et al., 2012), although recent statistics reported that in some European countries (i.e., France, Croatia) wine represents an important part $(c a .10 \%)$ of the organic market (Willer and Lernoud, 2015). Finally, fruit and vegetables are of considerable importance so that, in the north, represent 11.9 and $6.6 \%$ of total UAA (Table 4), thus tripling their contribution with respect to the overall agricultural system.

There are 3374 geographical indication products worldwide (labelled following the EU certification of PDO or PGI products), divided between the agri-food (1432) and wine (1942) sectors (Table 5) (last update, 26/01/2017). Most products are from EU-28 members (total 3311) and Italy, which is the leading country within the EU-28 with 833 GI products (295 agri-food and 538 wines sectors), contributes $25.2 \%$ of the total (Table 5). France and Spain are the second and third countries in terms of total GI products with 451 and 144 , respectively.

The number of GI products per region (Figure 6A), which was provided by the Italian Ministry of Agriculture, shows that Emilia Romagna has the largest number of typical agri-food products (43), followed by Veneto (35), Lombardy (34) and Sicily (30), while Molise and Aosta Valley only have 5 and 4, respectively (Figure 6A). Piedmont and Tuscany are instead the richest regions in terms of GI wines (both 58), followed by Veneto (52) (Figure $6 \mathrm{~B})$. As a result, the northern and central Italian regions are those with the largest number of GI products. Nevertheless, the analysis of regional GI products density (i.e., number GI/10,000 ha of total
UAA; Figure 6D) reveals different results: Liguria is the leading region, with $3.6 \mathrm{GI} / 10,000 \mathrm{ha}$, followed by the north-eastern regions (Veneto and Friuli-Venezia Giulia) and Tuscany with 1.1 GI/10,000 ha, while the lowest GI density (on average, $0.35 \mathrm{GI} / 10,000 \mathrm{ha})$ is found on the islands and in southern regions, particularly Apulia and Basilicata. These results suggest that the adoption of GI is much more relevant where there is a higher level of land diversification and heterogeneous areas (unproductive/naturalised areas, buffer zones, marginal woodlands, etc.). Indeed, a



Figure 5. Utilised agricultural area for organic farming (A) and geographical indications $(B)$ with respect to the total area (data source: ISTAT, 2010).

Table 4. Utilised agricultural area repartition within both organic farming and geographical indications systems as a result of the Italian agricultural census 2010 (data source: ISTAT, 2010).

\begin{tabular}{|c|c|c|c|c|c|c|c|c|c|c|}
\hline \multirow[t]{3}{*}{ Land use } & \multicolumn{10}{|c|}{ UAA repartition within the systems (\%) } \\
\hline & \multirow[b]{2}{*}{ North } & \multicolumn{4}{|c|}{ Organic farming } & \multicolumn{5}{|c|}{ Geographical indication } \\
\hline & & Centre & South & Islands & Italy & North & Centre & South & Islands & Italy \\
\hline Arable lands & 34.8 & 49.2 & 45.8 & 40.2 & 45.5 & 2.3 & 3.3 & 6.3 & 5.5 & 3.4 \\
\hline Cereals & 18.0 & 28.0 & 30.8 & 16.4 & 28.6 & 1.0 & 2.1 & 3.4 & 2.6 & 1.9 \\
\hline Industrial crops & 3.2 & 2.4 & 1.1 & 0.0 & 1.0 & 0.0 & 0.0 & 0.0 & 0.0 & 0.0 \\
\hline Fodder & 2.7 & 11.2 & 6.7 & 21.1 & 10.6 & 0.0 & 0.0 & 0.0 & 0.0 & 0.0 \\
\hline Vegetables & 6.6 & 1.1 & 3.9 & 1.2 & 2.1 & 0.8 & 0.4 & 2.3 & 2.8 & 1.1 \\
\hline Fallow & 0.0 & 0.0 & 0.0 & 0.0 & 0.0 & 0.0 & 0.0 & 0.0 & 0.0 & 0.0 \\
\hline Others & 4.4 & 6.5 & 3.4 & 1.5 & 3.2 & 0.2 & 0.8 & 0.5 & 0.1 & 0.4 \\
\hline Permanent crops & 22.9 & 27.3 & 41.2 & 17.4 & 31.6 & 97.7 & 96.5 & 93.7 & 94.2 & 96.4 \\
\hline Vineyards & 8.4 & 8.0 & 8.3 & 3.9 & 5.6 & 76.5 & 66.8 & 66.3 & 69.4 & 69.7 \\
\hline Olive groves & 2.7 & 14.5 & 22.0 & 8.5 & 17.2 & 9.6 & 27.2 & 21.9 & 14.6 & 16.8 \\
\hline Citrus groves & 0.0 & 0.0 & 2.4 & 2.5 & 3.0 & 0.0 & 0.0 & 2.0 & 9.7 & 1.3 \\
\hline Fruit plantations & 11.9 & 4.8 & 8.4 & 2.5 & 5.8 & 11.6 & 2.5 & 3.5 & 0.4 & 8.6 \\
\hline Others & 0.0 & 0.0 & 0.0 & 0.0 & 0.0 & 0.0 & 0.0 & 0.0 & 0.0 & 0.0 \\
\hline Pastures and meadows & 41.1 & 21.8 & 12.4 & 41.7 & 22.1 & 0.0 & 0.0 & 0.0 & 0.0 & 0.0 \\
\hline Other uses & 1.2 & 1.7 & 0.5 & 0.7 & 0.9 & 0.1 & 0.2 & 0.0 & 0.3 & 0.1 \\
\hline
\end{tabular}

UAA, utilised agricultural area. 
positive correlation $\left(\mathrm{R}^{2}=0.75 ; \mathrm{P}<0.01\right)$ was observed between heterogeneous areas (as defined by land use data) and regional GI products density, emphasising their benefits in the preservation of more extensive agricultural practices (Lamarque and Lambin, 2015) and cultural landscapes (Riccheri et al., 2007). Nevertheless, no general correlation between the Italian pedo-climatic diversity and OF-GI systems was observed, likely due to a much more complex interaction with local aspects (e.g., rural culture and local economies). Finally, some uncertainties could arise from the GI density index since GI and UAA referred to different years,


Figure 6. Regional distribution of geographical indications in Italy (data source: Italian Ministry for Agriculture database). 
although differences in the comparison between regions are negligible since slightly affected by changes in the UAA.

Contrary to what is observed for $\mathrm{OF}$, geographical indications are mostly widespread in northern and central Italy (Figure 4C), covering up to $11 \%$ of total UAA in Trentino-South Tirol, followed by Tuscany $(9.8 \%)$, Veneto $(7.5 \%)$ and Friuli-Venezia Giulia (7.1\%). Conversely, only $0.4 \%$ of total regional UAA is managed for GI production in Basilicata. As a result, the northern regions of Trentino-South Tirol, Veneto and Friuli-Venezia Giulia are those markedly inclined towards GI products, while the southern regions of Calabria, Basilicata, Apulia and Sicily mostly favour OF ones (Figure 7). According to Vermeir and Verbeke (2006), this reflects that different schemes are selected to provide quality food products across Italy whose adoption (either OF or GI systems) contributes to the improvement of agro-system sustainability. Land used for GI products is $3.6 \%$ in Italy, while land for $\mathrm{OF}$ is $6.1 \%$. As a result, at national level, UAA managed for labelled quality products (GI and OF) contribute nearly $10 \%$ of the total. Nevertheless, since OF and GI are seldom characterised by distinct ways to target different environmental issues (e.g., Bérard and Marchenay, 2006; Fleskens et al., 2009; Stockdale et

Table 5. Distribution of geographical indications regarding agrifood and wine products (data from European and the Italian Ministry of Agriculture databases).

\begin{tabular}{lcccc} 
& Agri-food & $\begin{array}{c}\text { Gls }(\mathrm{n}) \\
\text { Wines }\end{array}$ & $\begin{array}{c}\text { Total } \\
\text { contribution's (\%) }\end{array}$ \\
North & 162 & 223 & 385 & - \\
Centre & 78 & 136 & 214 & - \\
\hline South & 84 & 115 & 199 & - \\
Islands & 38 & 64 & 102 & - \\
\hline Italy & 295 & 538 & 833 & - \\
EU-28 & 1385 & 1926 & 3311 & 25.2 \\
\hline Extra-EU & 47 & 16 & 63 & - \\
World & 1432 & 1942 & 3374 & 24.7 \\
\hline
\end{tabular}

GIs, geographical indications.

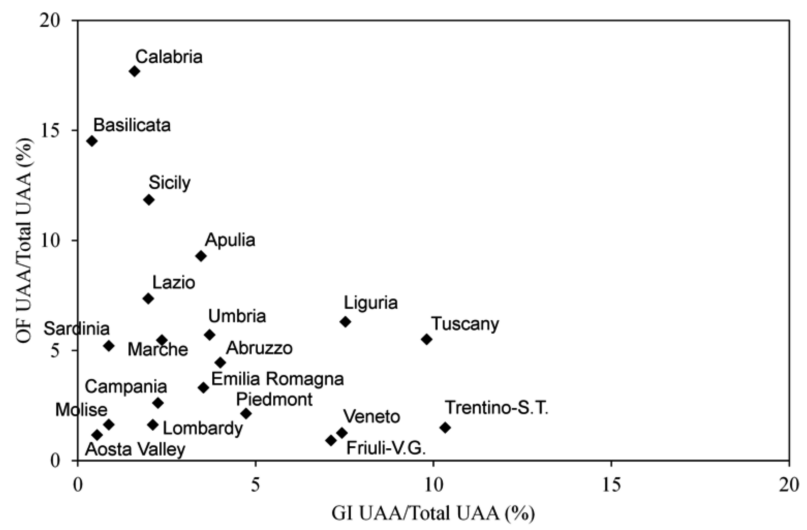

Figure 7. Relationship between regional distributions of utilised agricultural areas for geographical indications and organic farming (data source: ISTAT, 2010). al., 2001), such as maintaining landscape and biodiversity, lowering human impacts on soil and water resources, etc., their combination into an more integrated system is also advisable.

A significant decrease in regional farm size was observed for GI (Figure 4D) with respect to OF (Figure 4B), since a maximum of $5.1 \mathrm{ha} /$ farm for GI (found in Friuli-Venezia Giulia) is even lower than the minimum one in OF (Trentino-South Tirol). Hilly areas are more frequently managed for GI productions than the mountains and lowlands, reaching a peak of $11.7 \%$ in the north (Figure 5B), apart from on the islands where the UAA of geographical indications are greater in the plain areas. In general, these observations are in agreement with others: for instance Barjolle and Sylvander (2002) reported that several GI products are located in less-favoured lands in terms of agricultural intensification (e.g., hilly or mountain areas) as they allow for more small-scale labour-intensive economic efficiency. These aspects might be integrated with those discussed by Bérard and Marchenay (2006), who argued that GI farming is an alternative model to the essentially productive one, associating localised extensive practices with biological and landscape diversity. GI areas are mostly managed with permanent crops (Table 4) from north to south, especially vineyards $(96.4 \%$ of total UAA at national level) and olive groves (16.8\% of total UAA at national level), which are partly replaced by citrus groves on the islands $(9.7 \%)$. As a result, the great contribution of wine products to the total number of GI ones (Table 5, 66\%) is also supported by the total area of vineyards. In this context Cohen et al. (2015), analysing the plant biodiversity of Mediterranean agricultural systems as indicator of multifunctional and sustainable cultural landscapes, observed medium to high plant diversity in vineyards and olive groves where economic valuation relies not only on productivity, but also on heritage and landscape values, promoting high quality products. These findings corroborate previous results where the authors considered arboriculture per se as an intermediary case positioned between intensive and extensive agro-systems due to average or little disturbance if compared with other types of farming (Bruggisser et al., 2010; Camarsa et al., 2010).

\section{Conclusions}

Italian agriculture for quality food production is widely spread across the national territory, highlighting a major role in the European context that is favoured by a great variety in terms of pedo-climatic and orographic conditions. OF and GI systems cover around $10 \%$ of the national UAA, generating almost $25 \%$ of the Italian agriculture value production. Organic farms are generally larger than the average national size, while GI farms are the opposite. Different dynamics in terms of farm size and agricultural systems diffusion were observed in the different regions, particularly due to their pedo-climatic and orographic characteristics. In this context, OF are generally more frequent in southern Italy and on the islands, particularly in the hilly and mountain areas. By contrast, GI farms, mostly found in the central and in the northern regions, are located in less-favoured lands in terms of agricultural intensification (e.g., hilly or mountainous areas) as they allow for more small-scale labour-intensive economic efficiency. In this context, they play a positive role in preserving the presence of agriculture in these geographical conditions and, more generally, in preventing the abandonment of land. 


\section{References}

Aprile MC, Caputo V, Nayga Jr RM, 2012. Consumers' valuation of food quality labels: the case of the European geographic indication and organic farming labels. Int. J. Consum. Stud. 36:158-65.

Barjolle D, Sylvander B, 2002. Some factors of success for origin labelled products in agri-food supply chains in Europe: market, internal resources and institutions. Econ. Soc. 25:1441-64.

Belletti G, Brunori G, Marescotti A, Rossi A, van Huylenbroeck G, Durand G, 2003. Multifunctionality and rural development: a multilevel approach. In: G. Van Huylenbroeck, G. Durand, C. Folke (eds.) Multifunctional agriculture: a new paradigm for European agriculture and rural development, pp. 55-80. Ashgate Publishing Ltd., Hampshire, UK.

Belletti G, Marescotti A, Sanz-Cañada J, Vakoufaris H, 2015. Linking protection of geographical indications to the environment: evidence from the European Union olive-oil sector Land Use Policy 48:94-106.

Benaki V, Salvati L, Barone PM, Ferrara C, 2012. Comparing agricultural land-use statistics from different sources: a case study in Greece. Int. J. Lat. Trend. Financ. Econ. Sci 2:211-27.

Bérard L, Marchenay P, 2006. Local products and geographical indications: taking account of local knowledge and biodiversity. Int. Soc. Sci. J. 58:109-16.

Bruggisser OT, Schmidt-Entling MH, Bacher S, 2010. Effects of vineyard management on biodiversity at three trophic levels. Biol. Conserv. 143:1521-8.

Camarsa G, Gardner S, Jones W, Eldridge J, Hudson T, Thorpe E, O'Hara E, 2010. LIFE among the olives: Good practice in improving environmental performance in the olive oil sector. Official Publications of the European Union, Luxembourg.

Chever T, Renault C, Renault S, Romieu V, 2012. Value of production of agricultural products and foodstuffs, wines, aromatised wines and spirits protected by a geographical indication (GI) Final report. European Commission, Brussels, Belgium.

CLC, 2012. Corine Land Cover 2012. Available from: http://www.sinanet.isprambiente.it/it/sia-ispra/downloadmais/corine-land-cover/corine-land-cover-2012/view

Cohen M, Bilodeau C, Alexandre F, Godron M, Andrieu J, Grésillon E, Garlatti F, Morganti A, 2015. What is the plant biodiversity in a cultural landscape? A comparative, multiscale and interdisciplinary study in olive groves and vineyards (Mediterranean France). Agr. Ecosyst. Environ. 212:175-86.

Costantini EAC, Fantappié M, L'Abate G, 2013. Climate and pedoclimate of Italy. In: E.A.C. Costantini, C. Dazzi (eds.) The soils of Italy, pp 19-37. Springer, Dordrecht, The Netherlands.

Costantini EAC, Urbano F, L'Abate G, 2004. Soil regions of Italy. CRA-ISSDS, Firenze, Italy.

Dal Ferro N, Cocco E, Lazzaro B, Berti A, Morari F, 2016. Assessing the role of agri-environmental measures to enhance the environment in the Veneto Region, Italy, with a modelbased approach. Agric. Ecosyst. Environ. 232:312-25.

Deselnicu OC, Costanigro M, Souza-Monteiro DM, McFadden DT, 2013. A meta-analysis of geographical indication food valuation studies: what drives the premium for origin-based labels. J. Agr. Resour. Econ. 38:204-19.

European Commission, 1991. Organically grown agricultural products and foodstuffs. The Regulation establishes a harmonised framework for the production, labelling and inspection of agricultural products and foodstuffs in order to increase consumer confidence in such products and ensure fair compe- tition between producers, 2092/91/EEC. European Commission, Brussels, Belgium.

European Commission, 1992. 2081/92/EEC. Council Regulation 2081/92/EEC, application for registration PDO, Article 17. European Commission, Brussels, Belgium.

European Commission, 2007. Council Regulation of 28 June 2007 on organic production and labelling of organic products and repealing Regulation (EEC) No 2092/91834/2007/EC, 834/2007/EC. In: Official Journal, L 189, 20.7.2007.

European Commission, 2008. Council Regulation of 29 April 2008 on the common organisation of the market in wine, amending Regulations (EC) No 1493/1999, (EC) No 1782/2003, (EC) No 1290/2005, (EC) No 3/2008 and repealing Regulations (EEC) No 2392/86 and (EC) No 1493/1999, 479/2008/CE. In: Official Journal, L 148/1, 6.6.2008.

European Commission, 2012a. Commission Implementing Regulation of 8 March 2012 amending Regulation (EC) No $889 / 2008$ laying down detailed rules for the implementation of Council Regulation (EC) No 834/2007, as regards detailed rules on organic wine, 203/2012/EU. In: Official Journal, L 71/42, 9.3.2012.

European Commission, 2012b. Regulation of the European Parliament and of the Council of 21 November 2012 on quality schemes for agricultural products and foodstuffs, 1151/2012/EU. In: Official Journal, L 343/1, 14.12.2012.

EUROSTAT, 2010. Farm Structure Survey (FSS). Available from: http://ec.europa.eu/eurostat

Finke PA, Hartwich R, Dudal R, Ibánez J, Jamagne M, King D, Montanarella L, Yassoglou N, 1998. Geo-referenced soil database for Europe - Manual of procedures Version 1.0. European Soil Bureau, ISPRA, Italy.

Fleskens L, Duarte F, Eicher I, 2009. A conceptual framework for the assessment of multiple functions of agro-ecosystems: A case study of Trás-os-Montes olive groves. J. Rural Stud. 25:141-55.

Hinojosa-Rodríguez A, Parra-López C, Carmona-Torres C, Sayadi S, 2014. Protected Designation of Origin in the olive growing sector: Adoption factors and goodness of practices in Andalusia, Spain. New Medit. 13:2-12.

ISTAT, 2010. Italian general agricultural census. Available from: http://dati-censimentoagricoltura.istat.it

L'Abate G, Costantini EAC, 2004. GeoDataBase pedoclimatico d'Italia. Available from: http://www.soilmaps.it/ita/pedoclima3.html

Lamarque P, Lambin EF, 2015. The effectiveness of marked-based instruments to foster the conservation of extensive land use: the case of Geographical Indications in the French Alps. Land Use Policy 42:706-17.

Malorgio G, Camanzi L, Grazia C, 2008. Geographical indications and international trade: evidence from the wine market. New Medit. 7:4-13.

Mann S, Ferjani A, Reissig L, 2012. What matters to consumers of organic wine? Brit. Food J. 114:272-84.

Parrott N, Wilson N, Murdoch J, 2002. Spatializing quality: regional protection and the alternative geography of food. Eur. Urban Reg. Stud. 9:241-61.

Pelorosso R, Leone A, Boccia L, 2009. Land cover and land use change in the Italian central Apennines: a comparison of assessment methods. Appl. Geogr. 29:35-48.

Riccheri M, Gorlach B, Schlegel S, Keefe H, Leipprand A, 2007. Assessing the applicability of geographical indications as a means to improve environmental quality in affected ecosystems and the competitiveness of agricultural products. 
European Commission Project, Brussels, Belgium.

Ronchi B, Nardone A, 2003. Contribution of organic farming to increase sustainability of Mediterranean small ruminants livestock systems. Livest. Prod. Sci. 80:17-31.

Special Eurobarometer 410, 2014. Europeans, agriculture and the common agricultural policy. European Commission, Brussels, Belgium. Available from: http://ec.europa.eu/agriculture/survey/2014_en.htm

Stockdale EA, Lampkin NH, Hovi M, Keatinge R, Lennartsson EKM, McDonald DW, Padel S, Tattersall FH, Wolfe MS, Watson CA, 2001. Agronomic and environmental implications of organic farming systems. Adv. Agron. 70:261-327.

Thévenod-Mottet E, 2010. Geographical indications and biodiversity. In S. Lockie, D. Carpenter (eds.) Agriculture, biodiversity and markets. Livelihoods and agroecology in comparative perspectives, pp. 201-12. Earthscan, London, UK.
Tuomisto HL, Hodge ID, Riordan P, MacDonald DW, 2012. Does organic farming reduce environmental impacts? - A meta-analysis of European research. J. Environ. Manage. 112:309-20.

Vermeir I, Verbeke W, 2006. Sustainable food consumption: exploring the consumer "attitude-behavioral intention" gap. J. Agr. Environ. Ethic. 19:169-94.

Willer H, Lernoud J, 2015. The world of organic agriculture. Statistics and emerging trends 2015. Research Institute of Organic Agriculture FiBL and IFOAM - Organics International, Bonn, Germany.

Willer H, Schaack D, 2015. Organic farming and market development in Europe. In: H. Willer, J. Lernoud (eds.). The world of organic agriculture. Statistics and emerging trends 2015, pp. 181-214. Research Institute of Organic Agriculture FiBL and IFOAM, Bonn, Germany. 